\title{
Corporate Board Diversity and Performance: Nonlinear Dynamics
}

\author{
By: Fujiao Xie, Ying Guo, Shirley Daniel and Xueqian Huang
}

\begin{abstract}
:
In 2018, California became the first state in the US to require gender diversity on public corporate boards in the state, and since then board gender diversity is a hot debate in the US. To provide timely evidence on this issue, we investigate the relation between corporate board diversity and financial performance and how shareholders' board gender diversity proposal impacts firm performance in the US. Consistent with the resource dependence theory and social identity theory, our findings show that the overall relation between board gender diversity and firm performance presents an inverted U-shaped nonlinear form. That is, when the corporate board becomes more gender-diverse, the gender-diverse board could incorporate different knowledge and non-redundant information in the decision-making process and gain a competitive advantage due to a better firm image of diversity. This indicates a positive effect of board diversity on corporate performance. However, while board diversity level reaches a turning point, the dysfunctional group processes (conflicts, miscommunication, and loss of trust caused by distinctiveness among different gender groups) outweigh the positive influences from gender diversity on firm performance through the deterioration of the quality of board decisions, showing that a negative relation between board diversity and firm performance emerges and becomes dominant. In addition, investors' active engagements through proxy proposals enhance the positive effect of diversity and alleviate the negative effect of diversity. Our study provides a different conceptual lens to evaluate the impact of board gender diversity on firm performance and provides insights for regulators to make proper decisions in increasing board diversity in the US.
\end{abstract}




\section{Corporate Board Diversity and Performance: Nonlinear Dynamics}

\section{INTRODUCTION}

For many years there have been pressures to increase the number of women on corporate boards of directors. In Europe, one of the primary means of increasing gender diversity on boards has been the imposition of quotas both through "hard law" and "soft law." These systems have been successful in increasing the number of women on boards in Europe over a relatively short time frame, so that the proportion of women on boards in the EU now ranges from 20 to 45 percent (Deloitte 2017). However, for many years, US regulators have resisted imposing any legal quotas for gender diversity on public boards, and the number of women on corporate boards in the US has hovered under twenty percent.

On September 30, 2018, California became the first state in the US to require gender diversity on their boards for public companies in the state (California Legislative Information, SB 826, 2018). The California law states that by the end of 2019, at least one female director should be included by the companies subject to the law. By the end of 2021, subject companies with five board members must have at least two female directors. If the companies have six or more board members, at least three female directors must serve on the board. Companies can face financial penalty for violations: $\$ 100,000$ fine for a first violation and $\$ 300,000$ fine for subsequent violations.

Advocates of gender diversity point out that a diverse board can provide not only the inherent value of societal gender equality but also the benefits of superior decision making, workforce motivation, market knowledge, and firm image. Robinson and Dechant (1997) conclude that greater workplace diversity (age, race, gender, etc.) improves firm performance. Campbell and Minguez-Vera (2008) adopt Robinson and Dechant's (1997) argument when they examine the relation between board diversity and firm performance for several reasons. First, greater diversity helps the firm understand the market, customers and employees better, which enhances the firm's market penetration ability. Second, as prior literature suggests, gender diversity promotes firm creativity and innovation by including broader perspectives in the decision-making process. Third, a gender diverse board could enhance a corporation's 
competitive advantage through the improvement of a firm image aligned with the societal gender equality movement. Therefore, a positive correlation exists between board gender diversity and firm performance.

However, prior literature also argues the negative effect of gender diversity on firm performance. The adverse impact of diversity comes from the dysfunctional group effect, which is due to the distinctiveness creates among different gender groups. When the board becomes more diverse, in-groups and out-groups may be formed regarding the gender difference. The dysfunctional dynamics are introduced and become more and more dominant. In this situation, dysfunctional dynamics cause conflicts, miscommunication, and loss of trust among the team (Earley and Mosakowski,2000; Tajfel and Turner, 1986; Williams and O'Reilly,1998; Lau and Murnighan,1998; Richard et al.,2004; etc.). Thus, the quality of board decisions deteriorates. The effectiveness and efficiency of the board function will be worsened. Due to both the positive effect and negative effects of gender diversity, we expect, firm performance improves with the increase of board gender diversity; however, when the board diversity ratio passes a certain threshold, the dysfunctional group processes outweigh the positive effects from the gender diversity and gradually becomes the dominating effect. As a result, a negative relation between board diversity and firm performance emerges.

Although numerous studies on board diversity and firm performance have been carried out, the conclusion of the relationship is mixed. Empirical results show the positive, negative, or no relationship between board gender diversity and firm performance in different studies based on observations from different countries and industries. The possibility of the inconsistency arises from the non-linear and compound effect of gender diversity on firm performance. The overall diversity impact on firm performance could be conditional upon the level of board gender diversity after the positive and negative effect nets out each other. Therefore, we propose an inverted-U non-linear shape describing the relation between board gender diversity and firm performance. Considering the legal and institutional context difference between European countries and the US, we specifically investigate the non-linear effects of board gender diversity and firm performance in US companies. To the best of our knowledge, this is the first empirical study using U.S. data to test the non-linear relationship between board gender diversity and corporate performance. 
Our study is also motivated in part by the US unique institutional and regulatory background on gender diversity, compared to its European counterparties. Unlike European countries, the majority of board members in the US remain male, and US regulators have resisted imposing any legal quotas to increase gender diversity. However, shareholders demand more corporate accountability, along with more diversity in board composition and improved social responsibility in corporate policies. Until recently, board diversity has been an increasingly hot topic in shareholder engagement. For example, large institutional investors, including Black Rock and Vanguard, and the CalPRS and CalSTRS pension funds have called for greater board diversity and greater proxy access, requesting more active dialogue and engagement with company and board leadership.

In the absence of regulatory requirements in the US in the past, activist investors have resorted to shareholder proxy access as a mechanism to encourage board gender diversity. In the context of such background, we then examine in more detail how activist investors in the US use proxy access procedures and initiatives to coerce boards to improve board diversity and how the proposal on board diversity changes firm performance in the US. Thus, the other objective of this research is to shed more light on how investors' board gender diversity proposal interferes with firm performance.

Using a sample of U.S. public companies from 1999 to 2018, we empirically examine the non-linear relation between board gender diversity and firm performance and the impact of activist proxy process in board diversity on performance. Our findings support that there is an inverted-U non-linear relation between board gender diversity and firm performance. That is, firm performance improves as the level of board gender diversity increases; however, the positive relationship between performance and board gender diversity may switch to negative relation when board diversity ratio reaches a certain threshold. Our results also show that shareholders' board diversity proxy is positively associated with firm performance. The results are robust to an alternative accounting measure of firm performance, as well as the treatment of potential endogeneity problems using the system GMM approach.

Built on the framework from prior literature (e.g., Ali et al. ,2011\& 2014; Frink et al., 2003; Joecks et al.,2013; Schwab et al., 2016), this study further explore and analyze the 
mechanics of gender diversity in boardroom and how it affects corporate operation outcome in the US through group decision. Specifically, we analyze the non-linear effect of board gender diversity on firm performance. Moreover, we investigate the impact of activist investors on firm decision-making process through shareholders' proposals, which could interfere with the dynamics between board gender diversity and firm financial performance. Our findings contribute to prior literature on board diversity in many ways. First, our results provide insight into the unique dynamics of financial markets and corporate governance systems in the US, which differ from those in other countries, both from a cultural as well as an institutional context. Second, this study contributes to the literature by providing further insights on the function of board gender diversity on firm performance, as an indication of the quality of group decision. Our findings suggest that a U-sharped non-linear relation between gender diversity in the boardroom and firm performance and then the overall influence of gender diversity on performance depends on the level of board gender diversity. The findings also support that shareholders' board diversity proxy process improves firm performance. Last but not least, this study provides useful evidence on board diversity to US regulators, since US regulators are taking actions to promote board diversity. For example, California became the first state in the US to require gender diversity by the end of 2019. Therefore, our findings should be of interest to regulators, board committees, investors and accounting researchers who are interested in board diversity and firm performance.

The rest of the article is organized as follows. "Literature Review and Hypothesis Development" section review the theoretical framework and perspectives on the corporate impact of gender diversity in the workplace, management team, and board members. "Research Design and Variable Definition" define variables and introduce regression models. "Sample and Results Discussion" section describes the sample and interprets the analysis results. The last section is "Conclusion", in which we summarize our research findings.

\section{LITERATURE REVIEW AND HYPOTHESIS DEVELOPMENT}

\section{Literature Review}


Within an organization, the demographic composition of a workgroup influences group processes; the outcomes of group process are measured as group performance; the aggregated group performance then become firm performance (Pfeffer, 1983\&1997; Frink et al., 2003). Therefore, the demographic composition within a workgroup is associated with firm performance.

\section{The Positive Effect of Diversity on Firm Performance}

In the past, many studies address the age, race, ethnicity, and gender diversity and investigate the relation of demographic diversity and firm performance. Notably, the relation between gender diversity and firm performance has attracted much attention (Ali et al., 2014; Joecks et al., 2013; Rhode and Packel, 2014; Simpson et al., 2010; etc.). Ali et al. (2014) and Joecks et al. (2013) document and tabulate the literature in detail on the topic of board gender diversity and firm performance.

The results from various studies are inconclusive and mixed: positive linear, negative linear, non-relationship and curvilinear relation all are observed when examining the association between gender diversity and firm performance outcomes. For example, some of articles claim a positive relation between gender diversity and firm performance (e.g., Bear et al. 2010; Bonn 2004; Bonn et al. 2004; Campbell and Mínguez-Vera 2008; Carter et al., 2003; Erhardt et al., 2003; Mahadeo et al. 2012; Nguyen and Faff 2006; Srinidhi et al. 2011).

Resource dependence theory (Pfeffer and Salancik, 1978) is adopted to explain empirical findings. Resource dependence theory claims that the performance of a firm depends on how successfully the firm obtains critical resources from the external stakeholders. Diverse boards better serve this external resource facilitation function (Hillman et al. 2007\&2009). First, a diverse board shows better market penetration ability since it could better understand and more effectively communicate with critical external stakeholders, such as customers, vendors, and shareholders, compared with a homogeneous board (Miller and Triana, 2009). The stronger ties between a firm and its critical external stakeholders increase the chance that a firm achieves financial success (Campbell and Minguez-Vera, 2008). 
Second, board members with different gender could bring different information, thoughts, skills, approaches, and knowledge. Therefore, a diverse board tends to incorporate different perspectives and redundant information. Also, male and female directors are different in detail-oriented or risk-averse aspects (Stendardi et al. 2006; Graham et al. 2002). Diverse boards have been proved to promote creativity and innovation (Talke et al., 2010). Being more inclusive in terms of information and thought process, inviting both male and female on the board, a board could improve its decision quality, which enhances firm performance (Ali et al., 2014; Rogelberg and Rumery, 1996).

Third, a diverse board improves the firm's image since it is aligned with the societal gender equality movement. The twofold of effects from this firm's public image improvement are: (1) The presence of diverse board members signals career advancement opportunities for minority groups and inspires them to work hard (Ali et al., 2014; Fredette et al. 2006; Stephenson 2004). Those minority talent employees could bring a firm's competitive advantage (Ali et al., 2014). (2) The firm's diversity figure could also plead its importance to external stakeholders who value gender equality. It strengthens the linkage between the firm and its stakeholders, secures the sustainable supports from those critical external parties, and thus results in the firm's financial success. To sum up, based on the resource dependence theory, board diversity strengthens the connection between a firm and its external stakeholders, improves decision quality, and realizes a competitive market advantage. Therefore, board diversity helps achieve financial success and a positive relation between board gender diversity and firm performance.

\section{The Negative Effect of Diversity on Firm Performance}

Controversially, some studies observe a negative relation between gender diversity and corporate performance (e.g., Adams and Ferreira 2009; Ahern and Dittmar 2012; Bøhren and Strøm 2010; Dobbin and Jung 2011; Haslam et al. 2010; He and Huang 2011; Shrader et al. 1997). Social identity theory (Tajfel 1978, Tajfel and Turner, 1979\&1986) explain such relation.

Based on social identity theory, individuals in society categorize themselves into different social groups according to demographic attributes. Individuals similar to them in demographic attributes are classified as in-group members, with perceptions of "us"; those dissimilar with 
them are called out-group members, with perceptions of "them". People treat "us" group members and "them" members differently (Brown and Turner, 1981). Bias also arises toward the out-group members as less cooperative and less trustworthy (Brewer, 1979). Prior literature indicates adverse outcomes of such self-categorization processes, such as increasing conflicts between groups, higher dissatisfaction of workplace, less trust between groups, more likely miscommunication across groups (Chatman and Flynn 2001; Chrobot-Mason et al., 2009; Jehn et al. 1999; Li and Hambrick, 2005; Pelled 1996).

The distinctiveness triggers dysfunctional group processes, which impede effective group decision making (Schwab et al, 2016). As the management team becomes diverse, gender-based groups turn into more closely in terms of power and influence. When there are disagreements among groups due to in-group and out-group segregation, the arising conflicts could become very intensive since the groups possess similar decision power and influence. Therefore, gender diversity after approaching parity level begins showing negative consequences on firm performance (Schwab et al., 2016). Similar to the above notion, board members make critical decisions and influence on a firm's strategic changes. When the board is more gender diverse, conflicts, distrust, and miscommunication among different gender groups might impede the board member team from including all relevant information for optimizing solutions and from identifying the best alternatives. Thus, gender diversity in the board room could negatively affect firm performance.

\section{Non-linear Relation between Gender Diversity and Firm Performance}

Several articles make a curvilinear prediction on the relation between gender diversity and firm performance (e.g., Ali et al. 2011\&2014; Frink et al. 2003; Joecks et al. 2013; Schwab et al. 2016). Brewer (1991) claims the existence of a state of balance in terms of the effects of group composition and suggests the curvilinear relation between group composition and organizational outcomes. Frink et al. (2003) argue that the gender diversity and firm performance relation would be a curvilinear form and the very low and very high levels of female representation are related to low firm performance and moderate levels of the female ratio are associated with better firm performance. Frink et al. (2003) rationalize their argument by referring to previous research on the association between tenure, functional background, age and 
race/ethnicity with organizational performance: organization performance benefits from the heterogeneity of demographic representation; when the workforce becomes more homogeneous in term of demographic attributes, the benefits of heterogeneity diminish. An optimal balance on workforce demographic composition exists. Thus, a curvilinear relationship is expected between employee gender diversity and firm performance.

Schwab et al. (2016) recognize the positive and negative effects of managerial gender diversity on firm performance. Gender diversity improves information access and analysis and therefore enhances managerial decision quality. As a result, managerial gender diversity is positively associated with firm performance. However, gender diversity could cause dysfunctional group processes due to social categorization and in-group and out-group distinctions (Tajfel, 1978). The distrust, miscommunication and conflicts among in-groups and out-groups diminish the decision-making advantages of diversity, eventually deteriorate the quality of the managerial decision, and result in worse firm performance after managerial gender diversity ratio passes certain optimal level. Schwab et al. (2016) also introduce tokenism when the minority group is first included to serve on the management team. According to Kanter (1977), token individuals act differently compared to the dominant group members. Tokens tend to communicate less and engage more in withdrawal-type behaviors (Liao et al, 2004) and they show more negative work attitudes (Tsui et al., 1992). Those conditions could lead to less managerial decision quality and unsatisfactory work performance. Therefore, when the minority gender group is introduced in the first place, it is associated with adverse outcomes for firm performance due to tokenism. As a result, Schwab et al. (2016) posit a non-linear relation with two turning points to capture the association between managerial gender diversity and firm performance: firm performance declines while gender diversity increase due to token effect; then firm performance increases when managerial gender becomes more diverse due to improvement of decision-making quality; however, after the gender ratio reaches an optimal level, firm performance decreases with the continuous increase of gender diversity since the dysfunctional group process becomes a dominant effect. In another study, referring to Kanter's (1977) critical mass theory, Joecks et al. (2013) provide empirical evidence of the token effect and conclude a U-shape function that descript the link between board gender diversity and firm performance. However, with regarding to the tokens' effect, Graves and Elsass (2005) conclude that it might be hard to show statistically significant when investigating tokens' effect on group interactions. 
Ali et al. (2014) integrate resource dependence theory (Pfeffer and Salancik, 1978) and social identity theory (Tajfel, 1978; Tajfel and Turner, 1979\&1986) and propose an inverted Ushape nonlinear relation between board age and gender diversity and firm performance. As discussed in the early part, resource dependence theory implies positive association and social identity theory suggests a negative association between gender diversity and firm performance. According to Ali et al. (2011, 2014), when considering both mechanisms at the same time, an inverted U-shaped curvilinear prediction is expected; the net marginal effects of diversity on outcomes vary based on the level of gender diversity. In Ali et al.'s (2014) study, using 288 large organizations listed on the Australian Securities Exchange, they observe the curvilinear relationship between age diversity and return on assets. They are not able to confirm the nonlinear relationship on the relation between board gender diversity and firm performance, probably due to the limited sample size.

However, we also notice that some studies found no significant impact of gender diversity on firm performance (e.g., Carter et al. 2010; Jhunjhunwala and Mishra 2012; Miller and del Carmen Triana, 2009; Randoy et al. 2006; Rose, 2007; Shukeri et al. 2012; Wang and Clift 2009). It could be explained by the mixed effects of gender diversity on firm performance: the benefits from gender diversity on firm decision making or firm's competitive advantage are offset by the negative effects of the dysfunctional decision process due to gender distinctiveness. When a linear model is employed, it might fail to capture the nonlinear relationship and turn out insignificant coefficients.

\section{Hypothesis Development}

Similar to Ali et al. (2014)'s notion, we propose an inverted U-shape function form between board gender diversity and firm performance. As gender diversity increases, the gender minority groups in the boardroom bring in access to some critical resources and information (e.g., a new body of knowledge, new skill set, different understandings, new perspectives) for decision making, those resources and information are not available to homogeneous gender groups. According to the resource dependence theory, better access to resources and nonredundant information enhance decision making quality and help the board find the optimal choice about the firm's operation, strategic movement and performance-related issues. In the 
long run, this helps the firm achieve high financial performance. Thus, we expect a positive effect of board gender diversity on firm performance. In addition, the better off gender diversity improves the firm's image and implies the commitment to diversity from the top. The benefit of a better firm diversity image is to provide minority groups in the firm an incentive to excel, which could increase innovations, workplace satisfaction, and productivities, and lead to many other positive performance outcomes. On the other hand, a better firm diversity image helps the firm to gain supports from the stakeholders (e.g., customers, vendors, creditors...) who value demographic equality. It helps the firm archive better bottom-line numbers. It could also increase the firm's market-based performance. To sum up, a positive effect of board gender diversity on firm performance is anticipated.

However, board gender diversity also comes with a negative impact on firm performance. According to social identity theory, individuals with different demographic attributes divide themselves into distinct groups: in-group and out-group. Individuals in different groups show bias and perceptions about their group and other groups. The distinctiveness and segregation bring in negative consequences, such as more conflicts, distrust, lack of communication, and less cooperative. Obviously, the negative consequences of distinctiveness worsen the board decision quality and result in worse firm performance. Therefore, if the effect of gender diversity from the social identity perspective dominated, we expect a negative correlation between board gender diversity and firm performance.

We expect both positive effect and negative effect of board gender diversity exist at the same time. However, the intensity/magnitude is various cross the different levels of the board gender diversity, which effect becomes dominated dependent on the level of board gender diversity. When the corporate board becomes more gender-diverse, group decision making quality improves comparing to homogeneous board composition scenarios. Even the diverse board introduces distinctiveness. However, the power and influence form minority groups are not strong enough to cause intensive conflicts. Therefore, the negative effect from the dysfunctional decision process is not the dominant effect; an overall positive correlation between board gender diversity and corporate performance is predicted. However, while board diversity level passes a certain threshold, conflicts between in-groups and out-groups become more intensive; the dysfunctional group processes will eventually outweigh the positive effects from the gender 
diversity and gradually becomes the dominated effect. Thus, the quality of board decisions deteriorates. As a result, a negative relation between board diversity and firm performance emerges. Therefore, we have our first hypothesis state as:

Hypothesis 1: The relation between firm performance and board gender diversity is positive when board gender diversity is relatively low and becomes negative when board gender diversity is more intense.

As the resource dependence theory suggests, stakeholders' supports are critical for firm performance. It is interesting to investigate how investors' active involvement changes the mechanism between board gender diversity and firm performance. Our second hypothesis predicts a significant effect of active investor engagement on firm performance, through shareholder's proxy on board gender diversity.

When a firm's shareholders raise a proxy proposal for the more gender-diverse board, it implies that when gender diversity increases as the shareholders suggest, the decisions from the board are more likely to gain supports from the shareholders after board gender homogenous concerns alleviated. The supports from shareholders are one of the most critical resources that the firm relies on for survival and growth. Therefore, the positive effect of board gender diversity on firm performance will be more prominent. Especially, a firm's marketable based performance indicator, such as Tobin_Q, is also expected to be positively related to shareholders' board gender diversity proxy. In addition, the board members from gender minority group feel that they have the backup and support from the shareholders, this feeling could mitigate the token effects to certain extends and change their withdrawal-type behaviors (Liao et al, 2004) and their negative work attitudes (Tsui et al., 1992). The proxy from shareholders offset the negative effects of gender diversity under tokenism. Therefore, we expect a significant positive correlation between shareholders' proxy proposal for board gender diversity and firm performance: 
Hypothesis 2: The relation between firm performance and shareholders' proxy proposal on board gender diversity is positive.

\section{RESEARCH DESIGN AND VARIABLE DEFINITION}

We use the regression model (1) to test our first hypothesis:

Tobin_Q $Q_{i t+1}=\beta_{0}+\beta_{1}$ PercFemale $_{i t}+\beta_{2}$ PercFemale $_{i t}{ }^{2}+\beta_{3}$ AvgTimeRole $_{i t}+\beta_{4}$ AvgNoQuals $_{i t}+$ $\beta_{5}$ IndepD_Rateit $_{2}+\beta_{6}$ Perc_InstOwnit $+\beta_{7}$ NoDirectorsit $+\beta_{8}$ SIZE $_{i t}+\beta_{9} L E V_{i t}+\beta_{10}$ RDIntensity $_{i t}+$ $\beta_{11 \text { SaleGrowth }}+$ Industry fixed effect $+\varepsilon$ it

where the subscripts refer to firm $i$ in year $\mathrm{t}$ or $t+1$ and

Tobin_ $Q=$ a measure of Tobin's Q as Campbell and Minguez-Vera (2008) and Bennouri et al. (2018), defined as the sum of market value of stock and the book value of total liabilities divided by the book value of total assets.

PercFemale $=$ a direct measure of gender diversity in the boardroom, defined as the percentage of female board members.

AvgTimeRole $=$ an average time of board members served on the board in the unit of year.

AvgNoQuals $=$ an average number of qualified board members who earn undergraduate level or above.

IndepD_Rate $=$ the ratio of independent directors on board.

NoDirectors $=$ the board size which measures as the total number of board directors.

Perc_InstOwn $=$ the total institutional ownership, defined in the form of the percentage of shares outstanding.

SIZE $=$ the logarithm of total assets.

$L E V=$ long-term debt scaled by total assets. 
RDIntensity $=$ Research and Development Intensity, measured as the Research and Development Expenses scaled by the total assets.

SaleGrowth = a measure of percentage growth of Sale during the year $\mathrm{t}$, defined as Sale at the

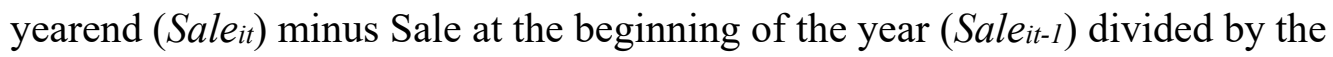
Sale at the beginning of the year $\left(\right.$ Sale $\left._{i t-1}\right)$.

To account for the nonlinearity between board gender diversity and firm performance, we specify a quadratic model that includes both the percentage of female board members (PercFemale) and its squared term (PercFemale ${ }^{2}$ ). We expect $\beta_{1}$ is positive and $\beta_{2}$ negative if the curvilinear function in the form of inverted U-shaped.

Equation (1) also includes control variables per previous studies (e.g., Bennouri et al.,2018; Campbell and Minguez-Vera, 2007). Consistent with Bennouri et al. (2018), we expect negative coefficients on Board independence (IndepD_Rate), firm leverage ratio (LEV) and a positive coefficient on firm size (SIZE) and Sale growth (SaleGrowth). We further add average time for directors on board (AvgTimeRole), the average number of the qualified board member who earns undergraduate level or above degree (AvgNoQuals) to account for the effect of time length served on board and qualification of board members which have impacts on the decision quality and therefore on the firm performance. Finally, equation (1) includes industry fixed effects to control for the variation of earnings quality across industries. All standard errors are adjusted for firm and year clustering to mitigate the potential autocorrelation problem.

To test our second hypothesis, we include DivProp into our regression model. DivProp is a dummy variable to indicate whether a firm's shareholders initiate proxy votes on board gender diversity. DivProp is equal to 1 when a firm's shareholders proposal for increase board gender diversity; otherwise, DivProp is equal to 0. We expect that the coefficient of DivProp is positive.

\footnotetext{
Tobin_Q $Q_{i t+1}=\beta_{0}+\beta_{1}$ PercFemale $i t+\beta_{2}$ PercFemale $_{i t}{ }^{2}+\beta_{3}$ DivProp $_{i t}+\beta_{4}$ AvgTimeRole $_{i t}+$ $\beta_{5}$ AvgNoQualsit $+\beta_{6}$ IndepD_Rateit $+\beta_{7}$ Perc_InstOwn ${ }_{i t}+\beta_{8}$ NoDirectorsit $+\beta_{9} S_{\text {SIZE }}{ }_{i t}+\beta_{10} L E V_{i t}+$ $\beta_{11}$ RDIntensity $_{i t}+\beta_{12}$ SaleGrowth $_{i t}+$ Industry fixed effect $+\varepsilon_{i t}$ 


\section{SAMPLE AND RESULTS DISCUSSION}

\section{Sample}

Our initial sample consists of all U.S. firm-years between 1999 and 2017 from the Compustat, BoardEx, ISS, and Thomson Reuters Stock Ownership database. To avoid possible differences driven by sample differences, we use the same sample for the primary analyses and most robustness tests. For this purpose, we require data availability for all variables in our main regression and the alternative measures of firm performance. Because our primary firm performance measure requires data for one lead year, we also download 2018 data from Computat. Our final sample consists of 6,036 firm-years.

\section{Descriptive statistics}

Table 1 presents the descriptive statistics of our main variables. In this table and all subsequent tables, we winsorize all the continuous variables at the $1 \%$ and $99 \%$ levels to mitigate the effects of outliers on our results. The mean (median) value of firm performance measure, Tobin_Q, is 1.960 (1.538), similar to that reported in the literature (e.g., Campbell and MinguezVera, 2008). The mean (median) of gender diversity measure, PercFemale, is 0.133 (0.125), with a standard deviation of 0.096 . The comparison of the standard deviation of PercFemale relative to its mean value suggests that our sample has a broad range of variation in gender diversity, thus a powerful setting for testing the hypothesized nonlinear relation.

The correlations among the main variables are presented in Table 2. The correlation between PercFemale and Tobin_Q is insignificant. PercFemale has positively correlated to ROA and $R O E$, two accounting base firm performance measures, which suggest that firm performance is better when board gender diversity increases. However, this result does not account for control variables and a possible nonlinearity between gender diversity and firm performance. Turning to other variables, Tobin_ $Q$ is significantly correlated most of them, except for PercFemale, BlauIndex and AvgNoQuals. Below, we further examine the relation between PercFemale and Tobin_ $Q$ with both a nonparametric approach and regressions. 


\section{Results based on OSL Regression Analyses}

Equation (1) is employed to test the nonlinear relation between board gender diversity and firm performance. Per the results in Table 3, the coefficient on PercFemal is positive and the coefficient on PercFemale ${ }^{2}$ is negative, both highly significant (p-values $<0.05$ ). The results indicate (1) that higher board gender diversity enhances firm performance at a relatively low level of board gender diversity and (2) that as the board gender composition is more diverse, firm performance worsens. The results are consistent with our hypothesis 1. Turning to control variables, we find that firms with small board size, longer time serve as a board member, less institutional ownership, small firm size, lower leverage, more R\&D investment, and larger sale growth tend to have better firm performance. The coefficients on those control variables are overall consistent with previous studies (e.g., Ali et al., 2014, Campbell and Minguez-Vera, 2008, Bonnouri et al., 2018). The Adj. R-squared of $31 \%$ indicates that the independent variables in the model (1) explain a large extent of the variation in firm performance.

We include the dummy variable of DivProp, indicating whether the shareholders submit a proposal for a vote on increasing board gender diversity, into our regression model (Equation 2). The regression results are presented in Table 4. As we expected, the coefficient of DivProp is significant and positive, which means that the board gender diversity proposal raised by shareholders is positively associated with firm performance. Therefore, the empirical results approve our second hypothesis.

\section{Sensitive Tests: System GMM Approach}

System GMM estimation has been adopted in prior research to control for endogeneity concern (e.g., Arellano and Bover, 1995, Blundell and Bond, 1998; Bonnouri et al., 2018; Pathan and Faff, 2013). Following Bonnouri et al. (2018), we employ the system GMM technique and estimate the association between board gender diversity and firm performance in levels and first differences simultaneously. The level equation describes the function form of explanatory variables on the dependent variable and the difference equation presents the variation in year-toyear change of dependent variable on year-to-year change of explanatory variables. The lagged dependent variable and its year-to-year variations are also included in system GMM analysis. 
In addition, Return on Equity $(R O E)$ is another most common used firm financial performance measures in gender diversity and fir performance search (e.g., Bonnouri et al., 2018). We also use $R O E$ to replace Tobin_ $Q$ in Equation (1) and (2) to test whether the nonlinear relation exists. The analysis results are presented in Table 5. The coefficient of PercFemale is significant and positive and that of PercFemale ${ }^{2}$ is significant and negative. It captures the inverted U-shaped nonlinear relation between board gender diversity and firm performance. Also note that the coefficient of DivProp is positive, which suggests that shareholders actively engagement through a proposal on board gender diversity shows a positive influence on firm performance. The coefficient of DivProp is significant for Tobin_Q but not for ROE. It suggests that a market basis firm performance measure, Tobin_ $Q$, will react to Shareholder's actively engagement, through a proxy proposal, more comparing to accounting basis firm performance.

\section{CONCLUSION}

In this study, we investigate a nonlinear compound influence of board gender diversity on firm performance in the US and how shareholders' board diversity proxy process affects such dynamics between board diversity and firm performance. In contrast to prior research that investigates the linear relation on board diversity and performance in the US, we applied the resource dependence theory and social identity theory in board gender diversity and found an inverted U-shaped relation between board gender diversity and firm performance. We also find the positive impact of shareholders' board gender diversity proxy on firm performance. The results are robust to an alternative accounting measure of firm performance, as well as the treatment of potential endogeneity problems using the system GMM approach.

This study complements the existing research on board diversity in two important ways. First, it is the first study to examine the non-linear relation between board diversity and firm performance in the US setting. Our findings show that the relation between board gender diversity and firm performance is nonlinear, suggesting that the overall relation (that does not consider nonlinearity) could be positive, negative or insignificant relation, depending on whether the positive relation or the negative relation dominates or positive and negative effect balances the sample examined. Our findings are useful to US regulators since they are seeking regulatory 
actions to improve board diversity. The results also partly explain why the existing literature documents inconsistent conclusions regarding the impact of board diversity on firm performance. Second, we find that the shareholders activist involvement in board gender diversity could impact a firm's market performance positively. This study should benefit and interest to policymakers, practitioners, and academics, as it provides evidence for policy decision making related to board diversity and firm performance. 


\section{Reference:}

Adams, R. B., \& Ferreira, D. (2009). Women in the boardroom and their impact on governance and performance. Journal of Financial Economics, 94, 291-309.

Ahern, K. R.,\&Dittmar, A. K. (2012). The changing of the boards: The impact on firm valuation of mandated female board representation. The Quarterly Journal of Economics, 127, 137-197.

Ali, M., Kulik, C. T., \& Metz, I. (2011). The gender diversity-performance relationship in services and manufacturing organizations. International Journal of Human Resource Management, 22, 1464-1485.

Ali, M., Ng, Y. L., \& Kulik, C. T. (2014). Board age and gender diversity: A test of competing linear and curvilinear predictions. Journal of Business Ethics, 125, 497-512.

Arellano, M. , Bover, O. , 1995. Another look at the instrumental variables estimation of errorcomponents models. J. Econom. 68, 29-51.

Bennouri, M., Chtioui, T., Nagati, H, \& Nekhili, M. (2018). Female board directorship and firm performance: What really matters? Journal of Banking and Finance 88 (2018) 267-291.

Bear, S., Rahman, N., \& Post, C. (2010). The impact of board diversity and gender composition on corporate social responsibility and firm reputation. Journal of Business Ethics, 97, 207-221.

Blundell, R. , Bond, S. , 1998. Initial conditions and moment restrictions in dynamic panel data models. J. Econom. 87 (1), 115-143.

Bøhren, Ø., \& Strøm, R. Ø. (2010). Governance and politics: Regulating independence and diversity in the board room. Journal of Business Finance and Accounting, 37, 1281-1308.

Bonn, I. (2004). Board structure and firm performance: Evidence from Australia. Journal of the Australian and New Zealand Academy of Management, 10(1), 14-24.

Bonn, I., Toru, Y., \& Phillip, H. P. (2004). Effects of board structure on firm performance: A comparison between Japan and Australia. Asian Business and Management, 3(1), 105-125.

Brewer, M. B. (1979). In-group bias in the minimal intergroup situation: A cognitive-motivational analysis. Psychological Bulletin, 86, 307-324.

Brewer, M. B. (1991). The social self: On being the same and different at the same time. Personality and Social Psychology Bulletin, 17, 475-482.

Brown, R. J., \& Turner, J. C. (1981). Interpersonal and intergroup behaviour. In J. Turner \& H. Giles (Eds.), Intergroup behavior (pp. 33-65). Oxford, UK: Blackwell.

Campbell and Minguez-Vera, 2008, "Gender Diversity in the Boardroom and Firm Financial Performance”, Journal of Business Ethics, 83:435-451

California Legislative Information, SB 826, 2018

https://leginfo.legislature.ca.gov/faces/billTextClient.xhtml?bill_id=201720180SB826 
CalPRS Press Release.2016. Diverse Director DataSource Joins the Equilar Diversity Network (October 24, 2016), https://www.calpers.ca.gov/page/newsroom/calpers-news/2016/diversedirect-

datasource, retrieved November 26, 2017.

Carter, D. A., D’Souza, F., Simkins, B. J., \& Simpson, W. G. (2010). The gender and ethnic diversity of US boards and board committees and firm financial performance. Corporate Governance: An International Review, 18, 396-414.

Carter, D. A., Simkins, B. J., \& Simpson, W. G. (2003). Corporate governance, board diversity and firm value. The Financial Review, 38(1), 33-53.

Chatman, J. A., \& Flynn, F. J. (2001). The influence of demographic heterogeneity on the emergence and consequences of cooperative norms in work teams. Academy of Management Journal, 44, 956-974.

Chrobot-Mason, D., Ruderman, M. N., Weber, T. J., \& Ernst, C. (2009). The challenge of leading on unstable ground: Triggers that activate social identity fault lines. Human Relations, 62, 1763-1794.

City of New York, Office of the Comptroller. 2017. Board Accountability Project, and Board Accountability Project 2.0.

(https://comptroller.nyc.gov/services/financialmatters/boardroomaccountability-project/overview/) retrieved on November 26, 2017.

Deloitte "Women in the Boardroom: A Global Perspetive" Fifth Edition, Global Center for Corporate Governance, 2017

Dobbin, F., \& Jung, J. (2011). Corporate board gender diversity and stock performance: The competence gap or institutional investor bias? North Carolina Law Review, 89, 809-838.

Earley, P. C. and E. Mosakowski: 2000, 'Creating Hybrid Team Cultures: An Empirical Test of Transnational Team Functioning’, Academy of Management Journal 43, 26-49.

Erhardt, N. L., Werbel, J. D., \& Shrader, C. B. (2003). Board director diversity and firm financial performance. Corporate Governance, 11(2), 102-111.

Fredette, C., Inglis, S., \& Bradshaw, P. (2006). Moving to transformational inclusivity and board diversity. In Proceedings of the annual conference of the Administrative Sciences Association of Canada, Ottawa.

Frink, D. D., Robinson, R. K., Reithel, B., Arthur, M. M., Ammeter, A. P., Ferris, G. R., Kaplan, D. M., \& Morrisette, H. S. (2003). Gender demography and organization performance. Group \& Organization Management, 28, 127-147.

Graham, J. F., Stendardi, E. J., Jr., Myers, J. K., \& Graham, M. J. (2002). Gender differences in investment strategies: An information processing perspective. International Journal of Bank Marketing, 20, 17-26.

Graves, L. M., \& Elsass, P. M. (2005). Sex and sex dissimilarity effects in ongoing teams: Some surprising findings. Human Relations, 58, 191-221. 
Jehn, K. A., Northcraft, G. B., \& Neale, M. A. (1999). Why differences make a difference: A field study of diversity, conflict, and performance in workgroups. Administrative Science Quarterly, 44, 741-763.

Jhunjhunwala, S., \& Mishra, R. K. (2012). Board diversity and corporate performance: The Indian evidence. IUP Journal of Corporate Governance, 11(3), 71-79.

Joecks, J. K. Pull, \& K. Vetter (2013). Gender Diversity in the Boardroom and Firm Performance: What Exactly Constitutes a 'Critical Mass?' Journal of Business Ethics, 118, 61-72

Haslam, S. A., Ryan, M. K., Kulich, C., Trojanowski, G., \& Atkins, C. (2010). Investing with prejudice: The relationship between women's presence on company boards and objective and subjective measures of company performance. British Journal of Management, 21, 484-497.

He, J., \& Huang, Z. (2011). Board informal hierarchy and firm financial performance: Exploring a tacit structure guiding boardroom interactions. Academy of Management Journal, 54(6), 1119-1139.

Hillman, A. J., Cannella, A. A., Jr., \& Paetzold, R. L. (2000). The resource dependence role of corporate directors: Strategic adaptation of board composition in response to environmental change. Journal of Management Studies, 37, 235-255.

Hillman, A. J., Shropshire, C., \& Cannella, A. A., Jr. (2007). Organizational predictors of women on corporate boards. Academy of Management Journal, 50, 941-952.

Hillman, A. J., Withers, M. C., \& Collins, B. J. (2009). Resource dependence theory: A review. Journal of Management, 35, 1404-1427.

Kanter, R. M. (1977). Some effects of proportions on group life: Skewed sex ratios and response to token women. American Journal of Sociology, 7, 321-411.

Lau, D. C. and J. K. Murnighan: 1998, 'Demographic Diversity and Faultlines: The Compositional Dynamics of Organizational Groups', Academy of Management Review 23, 325-340.

Li, J., \& Hambrick, D. C. (2005). Factional groups: A new vantage on demographic faultlines, conflict, and disintegration in teams. Academy of Management Journal, 48, 794-813.

Liao, H., Joshi, A., \& Chuang, A. (2004). Sticking out like a sore thumb: Employee dissimilarity and deviance at work. Personnel Psychology, 57, 969-1000.

Mahadeo, J., Soobaroyen, T., \& Hanuman, V. (2012). Board composition and financial performance: Uncovering the effects of diversity in an emerging economy. Journal of Business Ethics, 105, 375-388.

Miller, T., \& del Carmen Triana, M. (2009). Demographic diversity in the boardroom: Mediators of the board diversity-firm performance relationship. Journal of Management Studies, 46(5), 755-786.

Mueller, Ronald O., and Ising, Elizabeth. 2017. Shareholder Proposal Developments during the 2017 Proxy Season. (July 12, 2017) Harvard Law School Forum on Corporate Governance and Financial Regulation, retrieved on November 28, 2017 from https://corpgov.law.harvard.edu/2017/07/12/shareholder-proposal-developments-during-the2017-proxy-season/ 
Nguyen, H., \& Faff, R. (2006). Impact of board size and board diversity on firm value: Australian evidence. Corporate Ownership \& Control, 4, 24-32.

Pathan, S. , Faff, R. , 2013. Does board structure in banks really affect their perfor- mance? J. Bank. Financ. 37 (5), 1573-1589.

Pelled, L. H. (1996). Demographic diversity, conflict, and work group outcomes: An intervention process theory. Organization Science, 7, 615-631.

Pfeffer, J. (1983). Organizational demography. In B. Staw \& L. Cummings (Eds.), Research in organizational behavior (Vol. 5, pp. 299-357). Greenwich, CT: JAI.

Pfeffer, J. (1997). New directions for organization theory: Problems and prospects. New York: Oxford University Press.

Pfeffer, J., \& Salancik, G. (1978). The external control of organizations: A resource-dependence perspective. New York: Harper and Row.

Rando“y, T., Oxelheim, L., \& Thomsen, S. (2006). A Nordic perspective on corporate board diversity. working paper, Nordic Innovation Centre, pp. 1-32.

Rhode, D. and A. Packel. (2014), Diversity on Corporate Boards: How Much Difference Does Difference Make? Delaware Journal of Corporate Law 39 , 377-425.

Richard, O. C., T. Barnett, S. Dwyer and K. Chadwick: 2004, 'Cultural Diversity in Management, Firm Performance, and the Moderating Role of Entrepreneurial Orientation Dimensions', Academy of Management Journal 47, 255-266.

Robinson, G. and K. Dechant: 1997, 'Building a Business Case for Diversity', Academy of Management Executive

$11,21-30$.

Rogelberg, S. G., \& Rumery, S. M. (1996). Gender diversity, team decision quality, time on task, and interpersonal cohesion. Small Group Research, 27, 79-90.

Rose, C. (2007). Does female board representation influence firm performance? The Danish evidence. Corporate Governance, 15(2), 404-413.

Shrader, C. B., Blackburn, V. B., \& Iles, P. (1997). Women in management and firm financial performance: An exploratory study. Journal of Managerial Issues, 9(3), 355-376.

Shukeri, S. N., Ong, W. S., \& Shaari, M. S. (2012). Does board of director's characteristics affect firm performance? Evidence from Malaysian public listed companies. International Business Research, 5, $120-127$.

Simpson, W. G., Carter, D. A., \& D’Souza, F. (2010). What do we know about women on boards? Journal of Applied Finance, 20(2), 27-39.

Stendardi, E. J., Graham, J. F., \& O'Reilly, M. (2006). The impact of gender on the personal financial planning process: Should financial advisors tailor their process to the gender of the client? Humanomics, $22,223-238$. 
Stephenson, C. (2004). Leveraging diversity to maximum advantage: The business case for appointing more women to boards. Ivey Business Journal, 69, 1-5.

Tajfel, H. (1978). Social categorization, social identity and social comparison. In H. Tajfel (Ed.), Differentiation between social groups: Studies in the social psychology of intergroup relations (pp. 61-76). London: Academic Press.

Tajfel, H., \& Turner, J. C. (1979). An integrative theory of intergroup conflict. In W. G. Austin \& S. Worchel (Eds.), The social psychology of intergroup relations (pp. 33-47). Monterey, CA: Brooks/Cole.

Tajfel, H. and J. Turner: 1986, 'The Social Identity of Inter-Group Behavior', in S. Worchel and W. Austin (eds.), Psychology and Intergroup Relations (Nelson-Hall, Chicago), pp. 7-24.

Talke, K., Salomo, S., \& Rost, K. (2010). How top management team diversity affects innovativeness and performance via the strategic choice to focus on innovation fields. Research Policy, 39, 907-918.

Tsui, A. S., \& O'Reilly, C. A. (1989). Beyond simple demographic effects: The importance of relational demography in superior-subordinate dyads. Academy of Management Journal, 32, 402-423.

Wang, Y., \& Clift, B. (2009). Is there a "business case" for board diversity? Pacific Accounting Review, 21(2), 88-103.

Williams, K. and C. O’Reilly: 1998, 'Forty Years of Diversity Research: A Review', in B. M. Staw and L. L. Cummings (eds.), Research in Organizational Behavior (JAI Press, Greenwich, CT), pp. 77-140. 
Table 1: Descriptive table for main variable in analysis.

\begin{tabular}{lrrrrrr}
\hline Variable & N & Mean & Std Dev & Median & 25th Pctl & $\begin{array}{r}\text { 75th } \\
\text { Pctl }\end{array}$ \\
\hline ROA & 6036 & 0.094 & 0.080 & 0.087 & 0.045 & 0.138 \\
ROE & 6036 & 0.121 & 0.339 & 0.127 & 0.066 & 0.198 \\
Tobin_Q & 6036 & 1.960 & 1.224 & 1.538 & 1.159 & 2.274 \\
divprop & 6036 & 0.022 & 0.148 & 0.000 & 0.000 & 0.000 \\
PercFemale & 6036 & 0.133 & 0.096 & 0.125 & 0.083 & 0.200 \\
BlauIndex & 6036 & 0.213 & 0.134 & 0.219 & 0.152 & 0.320 \\
NoFemale & 6036 & 1.460 & 1.108 & 1.000 & 1.000 & 2.000 \\
NoDIRECTORS & 6036 & 10.419 & 2.703 & 10.000 & 9.000 & 12.000 \\
Avgtimerole & 6036 & 6.211 & 2.523 & 5.916 & 4.500 & 7.434 \\
AvgNoQuals & 6036 & 2.047 & 0.458 & 2.071 & 1.778 & 2.333 \\
Lev & 6036 & 0.200 & 0.156 & 0.186 & 0.069 & 0.297 \\
RDInt & 6036 & 0.023 & 0.041 & 0.000 & 0.000 & 0.027 \\
SaleGrowth & 6036 & 0.078 & 0.196 & 0.060 & -0.012 & 0.144 \\
size & 6036 & 8.658 & 1.806 & 8.586 & 7.388 & 9.854 \\
INSTOWN_PERC & 6036 & 0.737 & 0.181 & 0.760 & 0.628 & 0.865 \\
\hline
\end{tabular}


Table 2: Correlation between variables in analysis (all correlation coefficients in bold are significant at a p-value of $1 \%$ or beyond).

\begin{tabular}{|c|c|c|c|c|c|c|c|c|c|c|c|}
\hline \multicolumn{12}{|c|}{ Pearson Correlation Coefficients, $N=6036$} \\
\hline & $(2)$ & $(3)^{\prime}$ & $(4)$ & (5) & $(6)^{\prime}$ & $(7)$ & $(8)^{\prime}$ & $(9)$ & $(10)^{\prime}$ & $(11)^{\prime}$ & (12) \\
\hline (1)Tobin_Q & 0.142 & -0.012 & -0.064 & -0.197 & -0.046 & 0.004 & -0.127 & 0.381 & 0.222 & -0.228 & 0.049 \\
\hline (2) ROE & 1 & $\mathbf{0 . 0 7 4}$ & $\mathbf{0 . 0 8 9}$ & $\mathbf{0 . 0 8}$ & 0.017 & 0.047 & -0.038 & -0.041 & $\mathbf{0 . 0 9 7}$ & 0.105 & 0.015 \\
\hline (3)PercFemale & & 1 & 0.93 & 0.267 & -0.09 & 0.212 & 0.102 & -0.122 & -0.132 & 0.352 & $\mathbf{0 . 0 5 4}$ \\
\hline (4)NoFemale & & & 1 & $\mathbf{0 . 5 3}$ & -0.07 & 0.256 & 0.109 & -0.159 & -0.137 & 0.507 & -0.019 \\
\hline (5)NoDIRECTORS & & & & 1 & 0.026 & 0.218 & 0.071 & -0.231 & -0.074 & 0.622 & -0.204 \\
\hline (6)Avgtimerole & & & & & 1 & -0.183 & -0.061 & -0.09 & -0.049 & -0.01 & -0.105 \\
\hline (7)AvgNoQuals & & & & & & 1 & 0.11 & 0.168 & -0.053 & $\mathbf{0 . 3 3}$ & $\mathbf{0 . 0 3 7}$ \\
\hline (8)Lev & & & & & & & 1 & -0.198 & -0.056 & 0.12 & 0.104 \\
\hline (9)RDInt & & & & & & & & 1 & 0.075 & -0.225 & 0.029 \\
\hline (10)SaleGrowth & & & & & & & & & 1 & -0.084 & 0.045 \\
\hline (11)size & & & & & & & & & & 1 & -0.092 \\
\hline (12)INSTOWN_PERC & & & & & & & & & & & 1 \\
\hline
\end{tabular}


Table 3: OLS Regression results for testing hypothesis 1.

\begin{tabular}{|c|c|c|c|}
\hline \multicolumn{4}{|c|}{ Dependent Variable $=$ Tobin $\_Q i, t+1$} \\
\hline & Coeff. & & t Value \\
\hline Intercept & 1.9284 & $* * *$ & $<.0001$ \\
\hline Perc_Female & 1.4928 & $* * *$ & 0.000 \\
\hline Perc_Female ${ }^{2}$ & -2.3550 & $* *$ & 0.045 \\
\hline NoBoardMembers & -0.0168 & $* * *$ & 0.004 \\
\hline AvgTimeRole & 0.0129 & $* * *$ & 0.009 \\
\hline AvgNoQuals & -0.0078 & & 0.819 \\
\hline IndepD_rate & 0.0048 & & 0.955 \\
\hline Inst_Own & -0.1616 & $*$ & 0.051 \\
\hline Size & -0.0373 & $* * *$ & 0.001 \\
\hline Lev & -0.2725 & ** & 0.030 \\
\hline RDIntensity & 6.1888 & $* * *$ & $<.0001$ \\
\hline SaleGrowth & 0.7952 & $* * *$ & $<.0001$ \\
\hline Industry fixed effects & & & Yes \\
\hline $\begin{array}{l}\text { Firm and year } \\
\text { clustering }\end{array}$ & & & Yes \\
\hline Adj. $R^{2}$ & & & $30.89 \%$ \\
\hline $\mathrm{N}$ & & & 6036 \\
\hline
\end{tabular}


Table 4: Regression results based on Equation 2, to test Hypothesis 2.

\begin{tabular}{lrlr}
\hline Dependent Variable=Tobin_Q $\mathrm{Q}_{\mathrm{i}, \mathrm{t}+1}$ & & & \\
\hline & Coeff. & & $\mathrm{t}$ Value \\
\hline Intercept & $1.9374^{* * *}$ & $<.0001$ \\
Perc_Female $^{* * *}$ & 1.6391 & ${ }^{* * *}$ & $<.0001$ \\
Perc_Female $^{2}$ & -2.6378 & ${ }^{* * *}$ & 0.025 \\
DivProp & 0.3477 & ${ }^{* * *}$ & 0.001 \\
NoBoardMembers & -0.0153 & ${ }^{* * *}$ & 0.008 \\
AvgTimeRole & $0.0124^{* *}$ & 0.012 \\
AvgNoQuals & -0.0020 & & 0.952 \\
IndepD_rate & 0.0022 & & 0.979 \\
Inst_Own & -0.1712 & ${ }^{* * *}$ & 0.038 \\
Size & -0.0412 & ${ }^{* * *}$ & 0.000 \\
Lev & -0.2648 & ${ }^{* *}$ & 0.035 \\
RDIntensity & 6.2397 & ${ }^{* * *}$ & $<.0001$ \\
SaleGrowth & 0.7982 & & $<.0001$ \\
& & & \\
Industry fixed effects & & & Yes \\
Firm and year clustering & & & Yes \\
Adj. $\mathrm{R}^{2}$ & & & $31.10 \%$ \\
N & & & 6036 \\
\hline
\end{tabular}


Table 5: System GMM Regression results based on Tobin_Q and ROA.

\begin{tabular}{|c|c|c|c|c|c|c|}
\hline \multicolumn{4}{|c|}{ Dependent Variable: Tobin_ $\mathrm{Q}_{\mathrm{i}, t+1}$} & \multicolumn{3}{|c|}{$\mathrm{ROE}_{\mathrm{i}, \mathrm{t}+1}$} \\
\hline & Coeff. & & $\mathrm{t}$ Value & Coeff. & & t Value \\
\hline Intercept & 22.0560 & *** & 3.190 & 12.5021 & *** & 2.100 \\
\hline Perc_Female & 41.1526 & $* * *$ & 5.250 & 35.1205 & $* * *$ & 5.940 \\
\hline Perc_Female ${ }^{2}$ & -44.1505 & $* *$ & -2.030 & -126.5730 & $* * *$ & -7.220 \\
\hline DivProp & 7.8360 & $* * *$ & 9.240 & 1.3599 & & 1.410 \\
\hline NoBoardMembers & -0.4023 & $* *$ & -2.100 & 0.3154 & ** & 2.280 \\
\hline AvgTimeRole & 0.1494 & & 1.020 & 0.2750 & ** & 2.150 \\
\hline AvgNoQuals & 3.1478 & * & 1.650 & -5.4968 & *** & -5.200 \\
\hline IndepD_rate & 0.2321 & & 0.210 & 10.5068 & $* * *$ & 6.080 \\
\hline Inst_Own & -0.6453 & & -1.260 & 2.2233 & $* * *$ & 2.600 \\
\hline Size & -2.7450 & $* * *$ & -5.320 & -1.6624 & $* * *$ & -3.150 \\
\hline Lev & -7.3545 & $* * *$ & -4.080 & 0.6731 & & 0.370 \\
\hline RDIntensity & -23.2474 & $* * *$ & -3.520 & -38.6472 & *** & -4.970 \\
\hline SaleGrowth & -0.5681 & $* * *$ & -2.710 & 0.9979 & $* * *$ & 2.880 \\
\hline Industry fixed effects & & & Yes & & & Yes \\
\hline Firm and year clustering & & & Yes & & & Yes \\
\hline $\mathrm{N}$ & & & 6036 & & & 6036 \\
\hline
\end{tabular}

*one lagged term of instrument variable is included and dependent variable are set as instrument variable in system GMM analysis. 
Figure 1: The illustration of relation between board gender diversity (measure as the percentage of female board members) and firm performance (measure as Tobin_Q in the lead year).

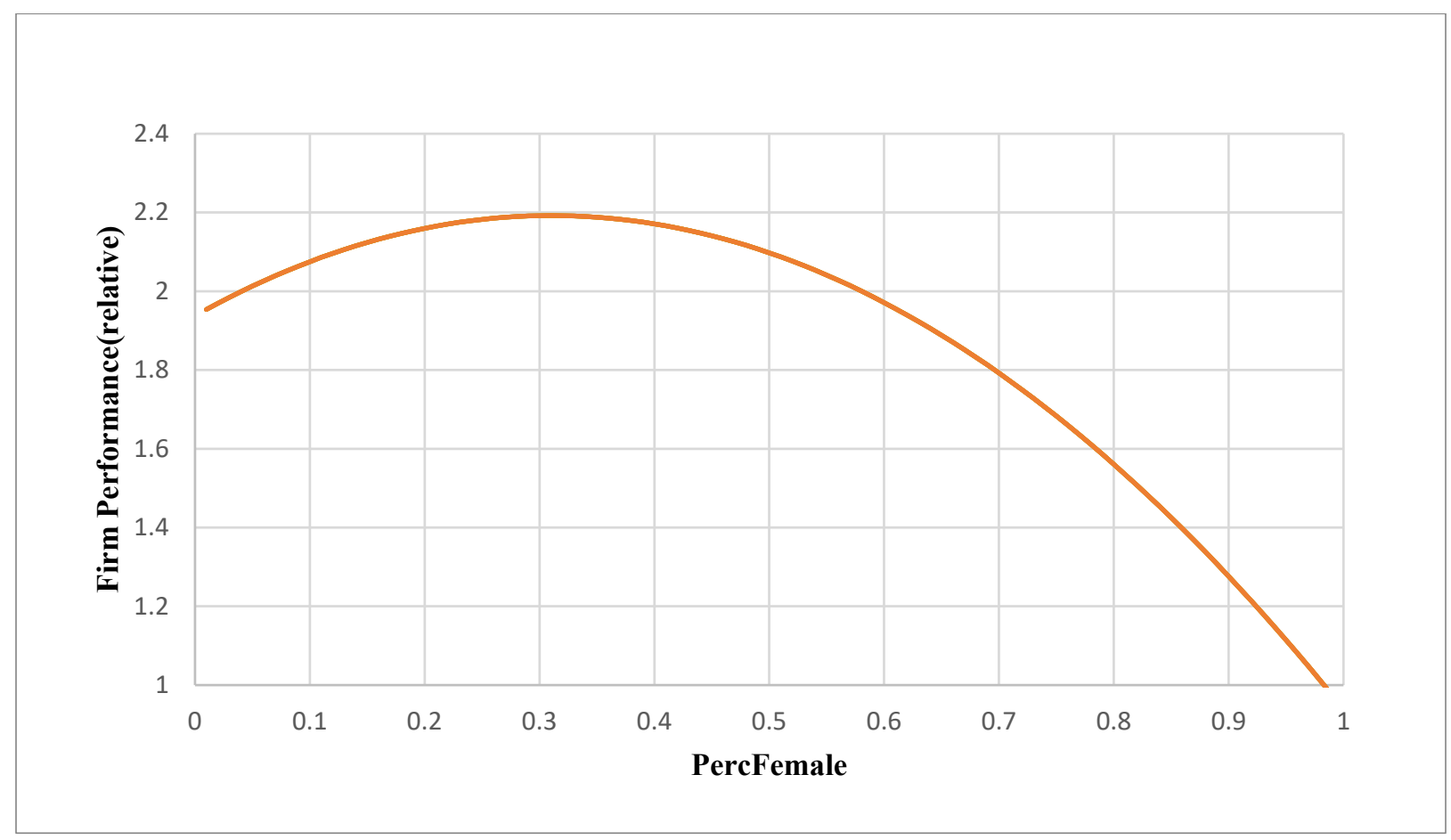

*The other control variables are omitted in plotting. 